\title{
THE EFFECTS OF SURGERY ON THE BLOOD LEVELS AND METABOLISM OF 17-HYDROXYCORTICOSTEROIDS IN MAN 1, 2
}

\author{
By AVERY A. SANDBERG, ${ }^{3}$ KRISTEN EIK-NES,4 LEO T. SAMUELS, AND \\ FRANK H. TYLER
}

(From the Departments of Medicine and Biochemistry, University of Utah College of Medicine,
Salt Lake City, Utah.)

(Submitted for publication April 7, 1954; accepted July 15, 1954)

The role of the adrenal cortex in the maintenance of homeostasis has been reviewed extensively by Sayers (1). It is evident from the experimental data published, as well as from observations on patients with adrenal insufficiency, that the adrenal cortex is necessary for the maintenance of life when untoward conditions are present in the environment. Such conditions have been referred to as "stresses" by Selye (2) and many others. "Stress," however, is such a nonspecific term that its use may lead to confusion. It has become apparent from studies in our laboratory that various noxious agents may have different effects on the circulating levels of 17-hydroxycorticosteroids. Consequently, the concept that all types of "stress" have a similar effect on adrenal secretion and adrenal steroid metabolism does not seem to be justified.

However, in a variety of such "stressful" circumstances (exposure to cold, trauma, histamine, etc.) in animals it has been demonstrated that a stereotyped series of events ensues which has been presumed to result from stimulation of the adrenal cortex by adrenocorticotrophic hormone (ACTH) $(1,3)$. In the adrenal cortex itself the changes have included depletion of ascorbic acid and cholesterol and increase in the weight of the gland. All of these are characteristic effects of ACTH

\footnotetext{
1 Some of these data were presented at the Annual Meeting of the Society for Clinical Investigation, Atlantic City, New Jersey, May 5, 1953.

2 This investigation was supported in part by research grants from the National Institutes of Health, U. S. Public Health Service and from Armour and Co. and in part by a contract (DA-49-007 MD-136) between the University of Utah and the Department of the Army.

${ }^{3}$ Scholar in Cancer Research of the American Cancer Society. The work presented in this paper was performed during the tenure of a Fellowship of the Dazian Foundation for Medical Research (1952-53).

4 Fulbright and Baxter Fellow.
}

administration. Such effects are not found after hypophysectomy.

It has also been demonstrated that certain metabolic changes which are similar to the effects which follow the administration of adrenocortical steroids are observable in both man and animals after trauma. A number of studies have shown, however, that although the presence of adrenal hormone is essential for the intensification of the adrenal-controlled metabolic processes following trauma, similar responses are produced in adrenalectomized animals maintained on constant doses of adrenal cortical extract, cortisone or hydrocortisone, where there can be no question of increased adrenal hormone secretion (4-6). Epinephrine, which Cannon (7) demonstrated long ago to be regularly increased after "stress" and trauma, appears not to produce a rise in plasma 17-hydroxycorticosteroid levels in the human but requires the presence of small amounts of adrenal cortical hormone for its adrenal-like metabolic effects to become manifest $(8,9)$.

These findings suggested that it might be important to evaluate the effect of the trauma of surgical operations on plasma levels of adrenal steroids and on their secretion. It has been demonstrated that the metabolic effects of surgery simulate in certain respects the effects of the administration of adrenal steroids $(10,11)$.

Sayers and Sayers (12) have presented evidence to support the hypothesis that the apparent stimulation of the adrenal cortex by "stress" might be the result of a compensatory response of the hypophysis to the utilization of circulating steroid by the "stressed" tissue. In this case one would expect that the 17-hydroxycorticosteroid level would first be decreased, stimulating the output of ACTH. Furthermore, the adrenal cortical capacity (ability to secrete additional amounts of 
adrenal steroids) might be expected to be impaired because of the increased spontaneous output. In order to examine this hypothesis, we have used a test of adrenal cortical capacity in man. This test is based on the effect of a maximally stimulating intravenous dose of ACTH on the circulating steroid levels. The details of the technique and the results in normal individuals have been presented in detail in an earlier paper (13). The effect of surgical trauma on the rate of disappearance of intravenously administered hydrocortisone was also determined.

\section{METHODS AND MATERIALS}

In patients undergoing surgery, blood samples were obtained by venesection when the patient arrived in the operating-room, following the induction of anesthesia, and at regular intervals during and following the surgical procedures. On certain patients control studies were performed at least one week before or four weeks after the operation.

All patients received the usual preoperative medications. These usually consisted of some barbiturate the night before and morphine and atropine on the morning of the operation.

Plasma 17-hydroxycorticosteroid levels were determined by a modification of the method of Eik-Nes, Nelson, and Samuels (14). The term 17-hydroxycorticosteroids, as used in this paper, is understood to refer to adrenal cortical steroids with a 17,21-dihydroxy-20-ketone group, such as cortisone, hydrocortisone, Reichstein's substance $\mathrm{S}$, and the hydrogenated derivatives of these compounds. The method, however, does not measure the conjugated forms of these steroids in plasma. Circulating eosinophils were counted by the method of Randolph (15).

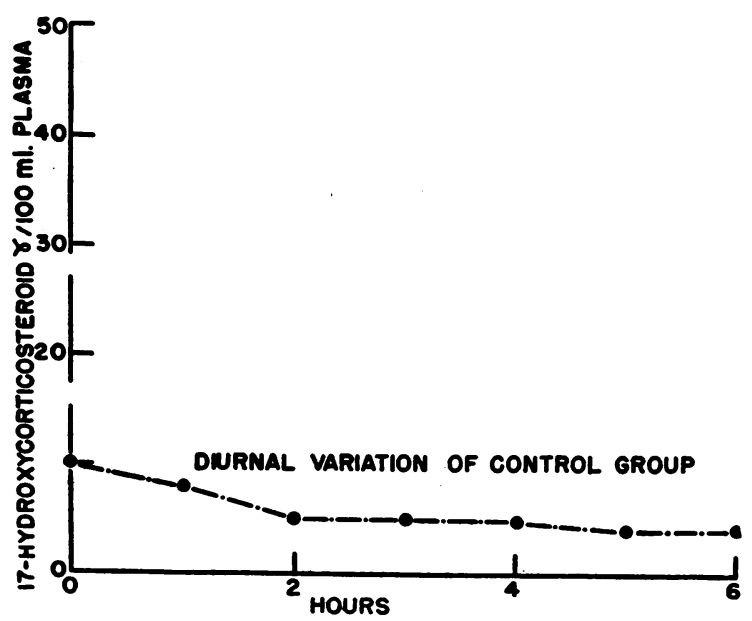

Fig. 1. Diurnal Variation of Plasma 17-HydroxyCoRTICOSTEROIDS, Begin NiNg AT 8 A.M. (0 Hours), in Normal Subjects
Adrenal cortical capacity was tested by the intravenous infusion of maximally stimulating amounts of ACTH over a 6-hour period (13). Venous blood samples were drawn for determination of plasma 17-hydroxycorticosteroid levels before and at 2, 4, and 6 hours after the infusion was started.

The ability to remove excess hydrocorticosterone was determined by the infusion of $50 \mathrm{mg}$. of hydrocortisone (free alcohol) in saline solution containing a small amount of ethanol (16).

\section{RESULTS}

\section{Plasma 17-hydroxycorticosteroid levels in normal subjects and the diurnal variations of these levels}

During the progress of these experiments plasma 17-hydroxycorticosteroids were determined in 84 non-surgical subjects. The average 8 A.M. level was $13 \mu \mathrm{g}$ per $100 \mathrm{ml}$. of plasma with a total range of 3 to $22 \mu \mathrm{g}$ per $100 \mathrm{ml}$. of plasma. The average curve of diurnal variation in normal individuals from this series is shown in Figure 1. It will be observed that the level is high in the morning (8 A.M.) with a gradual decline during the day, as previously described (17).

\section{Changes in plasma 17-hydroxycorticosteroids fol- lowing anesthesia}

It will be noted in Table I that none of the 12 patients in whom 17-hydroxycorticosteoid levels were measured at 8 A.M. before the induction of anesthesia showed a plasma 17-hydroxycorticosteroid level above the normal upper limit of $22 \mu \mathrm{g}$ per $100 \mathrm{ml}$. of plasma. The average is the same ( $13 \mu \mathrm{g}$ per $100 \mathrm{ml}$.) as that observed in a larger series of normal controls (17). Thus, neither the apprehension of the approaching surgical procedure nor the underlying clinical conditions had a significant effect on the plasma levels of 17-hydroxycorticosteroids. Following the induction of anesthesia the levels of 17-hydroxycorticosteroids rose to an average of $19 \mu \mathrm{g}$ per $100 \mathrm{ml}$. of plasma. Although the number of cases is small, it was interesting to note that the induction of general anesthesia (pentothal, cyclopropane, ether) was associated with an increase in the plasma 17-hydroxycorticosteroid levels in seven out of eight cases but that after induction of spinal anesthesia only one patient showed a higher level. Since this last value was higher than that found two 
TABLE I

Effect of anesthesia and surgery on plasma concentrations of 17-hydroxycorticosteroids

\begin{tabular}{|c|c|c|c|c|c|c|c|c|c|c|c|}
\hline \multirow[b]{2}{*}{ No. } & \multirow[b]{2}{*}{$\begin{array}{c}\text { Age and } \\
\text { sex }\end{array}$} & \multirow[b]{2}{*}{ Anesthesia } & \multicolumn{8}{|c|}{$\begin{array}{l}\text { 17-OH corticosteroids }(\gamma / 100 \mathrm{ml} .) \text { after } \\
\text { beginning of operation }\end{array}$} & \multirow[b]{2}{*}{ Operation } \\
\hline & & & $\begin{array}{l}\text { Before } \\
\text { anes- } \\
\text { thesia }\end{array}$ & $\begin{array}{l}\text { After } \\
\text { anes- } \\
\text { thesia } \\
\end{array}$ & $1 \mathrm{hr}$. & $2 \mathrm{hrs}$. & $3 \mathrm{hrs}$. & $4 \mathrm{hrs}$. & 5 hrs. & $6 \mathrm{hrs}$. & \\
\hline 1 & $59 \mathrm{~F}$ & $\begin{array}{l}\text { Pentothal and } \\
\text { cyclo then } \\
\text { ether }\end{array}$ & 15 & 23 & 26 & 47 & 52 & & 65 & & Cholecystectomy \\
\hline 2 & $70 \mathrm{~F}$ & $\begin{array}{l}\text { Pentothal and } \\
\text { ether }\end{array}$ & 18 & 25 & 26 & & 40 & & & & Smith-Peterson nailing \\
\hline 3 & $56 \mathrm{~F}$ & $\begin{array}{l}\text { Pentothal and } \\
\text { cyclo }\end{array}$ & 9 & 11 & 12 & 25 & 24 & 25 & & & Resection of lung \\
\hline 4 & $72 \mathrm{~F}$ & $\begin{array}{l}\text { Pentothal and } \\
\text { cyclo }\end{array}$ & 18 & 25 & 31 & 40 & 38 & & & & Cholecystectomy \\
\hline $\begin{array}{l}5 \\
6\end{array}$ & $\begin{array}{l}84 \mathrm{M} \\
65 \mathrm{~F}\end{array}$ & $\begin{array}{l}\text { Cyclo } \\
\text { Pentothal and } \\
\text { cyclo }\end{array}$ & $\begin{array}{r}4 \\
14\end{array}$ & $\begin{array}{r}9 \\
13\end{array}$ & 2 & $\begin{array}{r}4 \\
40\end{array}$ & $\begin{array}{r}5 \\
40\end{array}$ & 34 & & 42 & $\begin{array}{l}\text { Cholecystectomy } \\
\text { Abdominal-perineal re- } \\
\text { section of carcinoma of } \\
\text { colon }\end{array}$ \\
\hline 7 & $80 \mathrm{M}$ & $\begin{array}{l}\text { Pentothal and } \\
\text { cyclo }\end{array}$ & 12 & 33 & & 38 & & & & & Smith-Peterson nailing \\
\hline 8 & $56 \mathrm{M}$ & $\begin{array}{l}\text { Pentothal } \\
\text { cyclo and } \\
\text { ether }\end{array}$ & 10 & 27 & & 43 & 40 & 35 & & & $\begin{array}{l}\text { Gastrectomy (carci- } \\
\text { noma of stomach) }\end{array}$ \\
\hline \multirow[t]{2}{*}{$\begin{array}{r}9 \\
10 \\
11 \\
12\end{array}$} & $\begin{array}{l}70 \mathrm{M} \\
16 \mathrm{~F} \\
50 \mathrm{~F} \\
69 \mathrm{M}\end{array}$ & $\begin{array}{l}\text { Spinal } \\
\text { Spinal } \\
\text { Spinal } \\
\text { Spinal }\end{array}$ & $\begin{array}{r}9 \\
6 \\
20 \\
19\end{array}$ & $\begin{array}{r}9 \\
6 \\
17 \\
35\end{array}$ & $\begin{array}{l}20 \\
20\end{array}$ & $\begin{array}{l}26 \\
20 \\
30 \\
27\end{array}$ & & & & & \multirow[t]{2}{*}{$\begin{array}{l}\text { Prostatectomy } \\
\text { Appendectomy } \\
\text { Hemorrhoidectomy } \\
\text { Suprapubic prostatec- } \\
\text { tomy }\end{array}$} \\
\hline & & $\begin{array}{l}\text { Average } \\
\text { General } \\
\text { Spinal }\end{array}$ & 13 & $\begin{array}{l}19 \\
21 \\
17\end{array}$ & 20 & 31 & 34 & 33 & 65 & 42 & \\
\hline
\end{tabular}

hours later, during surgery, it may represent a technical error.

\section{Changes in plasma 17-hydroxycorticosteroid levels during surgery}

Table I shows the changes in the plasma 17hydroxycorticosteroids which took place during surgery in each of 12 patients. A gradual rise in the levels occurred which was especially striking when compared to the usual decrease in levels of plasma 17-hydroxycorticosteroids which occurs during this period of the day.

Case No. 5 was an exception to the general pattern observed. This patient was an 84-year-old white male who came to the hospital with severe jaundice due to calculi in the common bile duct. A cholecystectomy and exploration of the common bile duct were performed under cyclopropane anesthesia. The operation lasted three hours. The patient had no complications during or after surgery. On the assumption that the lack of any rise in 17-hydroxycorticosteroids in this patient might have been due to adrenal insufficiency, the patient was given an infusion of 25 I.U. of ACTH over
6 hours four weeks postoperatively. A normal rise in plasma 17-hydroxycorticosteroids occurred. We have no explanation for the lack of rise in his circulating steroids during surgery.

In the other patients there was a rise in the plasma 17-hydroxycorticosteroids during their operative procedures. There was a general tendency for the magnitude of the increase to be directly related to the duration of the procedure and its severity.

\section{Changes in plasma levels of 17-hydroxycorticos- teroids following operative procedures}

The 17-hydroxycorticosteroid levels immediately following 33 operations and at two hourly intervals thereafter are shown in Table II. Figure 2 demonstrates the average levels after surgery; the changes following procedures lasting less than two hours are compared with those lasting more than two hours. Although operations lasting two hours or less were associated with a rise in 17-hydroxycorticosteroid plasma levels during the procedure, there was little change thereafter. Levels, however, did not return to the preoperative 
TABLE II

Effect of surgery on plasma concentrations of 17-hydroxycorticosteroids following operational procedures

\begin{tabular}{|c|c|c|c|c|c|c|c|c|}
\hline \multirow[b]{2}{*}{ No. } & \multirow{2}{*}{$\begin{array}{l}\text { Age and } \\
\text { sex }\end{array}$} & \multirow{2}{*}{$\begin{array}{l}\text { Length } \\
\text { of op. } \\
\text { in hrs. }\end{array}$} & \multirow[b]{2}{*}{ Anesthesia } & \multicolumn{4}{|c|}{$\begin{array}{l}17-\mathrm{OH} \text { corticosteroids } \\
(\gamma / 100 \text { ml. }) \text { in plasma } \\
\text { after operation }\end{array}$} & \multirow[b]{2}{*}{ Operations and remarks } \\
\hline & & & & $0 \mathrm{hrs}$. & $2 \mathrm{hrs}$. & 4 hrs. & $6 \mathrm{hrs}$. & \\
\hline $\begin{array}{l}13 \\
14 \\
15 \\
16 \\
17 \\
18 \\
19 \\
20 \\
21\end{array}$ & $\begin{array}{l}60 \mathrm{M} \\
65 \mathrm{M} \\
60 \mathrm{M} \\
40 \mathrm{M} \\
52 \mathrm{~F} \\
55 \mathrm{M} \\
50 \mathrm{M} \\
35 \mathrm{~F} \\
57 \mathrm{~F}\end{array}$ & $\begin{array}{l}2 \\
4 \\
2 \\
1 \frac{1}{2} \\
4 \frac{1}{2} \\
4 \frac{1}{2} \\
4 \frac{3}{4} \\
4 \\
4 \frac{1}{2}\end{array}$ & $\begin{array}{l}\text { General } \\
\text { High spinal } \\
\text { High spinal } \\
\text { High spinal } \\
\text { General } \\
\text { High spinal } \\
\text { General } \\
\text { General } \\
\text { General }\end{array}$ & $\begin{array}{r}21 \\
23 \\
14 \\
5 \\
60 \\
20 \\
34 \\
15 \\
38\end{array}$ & $\begin{array}{l}20 \\
46 \\
22 \\
17 \\
40 \\
35 \\
21 \\
46\end{array}$ & $\begin{array}{l}19 \\
84 \\
20 \\
19 \\
48 \\
68 \\
45 \\
38 \\
53\end{array}$ & $\begin{array}{r}18 \\
102 \\
20 \\
25 \\
24 \\
100 \\
29 \\
31 \\
148\end{array}$ & $\begin{array}{l}\text { Removal of kidney stone } \\
\text { Gastrectomy } \\
\text { Prostatectomy } \\
\text { Renal stone removed } \\
\text { Cholecystectomy } \\
\text { Cholecystectomy } \\
\text { Bilateral thoraco-lumbar sympathectomy } \\
\text { Cholecystectomy } \\
\text { Ca of pancreas. Jejuno-choledocostomy. } \\
\text { Patient went into shock at end of op. } \\
\text { Resp. poor }\end{array}$ \\
\hline $\begin{array}{l}22 \\
23 \\
24\end{array}$ & $\begin{array}{l}30 \mathrm{~F} \\
38 \mathrm{M} \\
68 \mathrm{M}\end{array}$ & $\begin{array}{l}3 \\
4 \\
1 \frac{1}{2}\end{array}$ & $\begin{array}{l}\text { General } \\
\text { General } \\
\text { Spinal }\end{array}$ & $\begin{array}{l}20 \\
28 \\
10\end{array}$ & $\begin{array}{l}26 \\
42 \\
10\end{array}$ & $\begin{array}{l}26 \\
30 \\
17\end{array}$ & $\begin{array}{l}20 \\
21 \\
19\end{array}$ & $\begin{array}{l}\text { Thyroidectomy } \\
\text { Atrial appendectomy } \\
\text { Bilateral sympathectomy for arterioscle- } \\
\text { rosis }\end{array}$ \\
\hline $\begin{array}{l}25 \\
26 a\end{array}$ & $\begin{array}{l}42 \mathrm{M} \\
68 \mathrm{~F}\end{array}$ & $\begin{array}{l}3 \\
1 \frac{3}{6}\end{array}$ & $\begin{array}{l}\text { General } \\
\text { Pentothal and } \\
\mathrm{NO}_{2}\end{array}$ & $\begin{array}{l}19 \\
18\end{array}$ & $\begin{array}{l}21 \\
10\end{array}$ & $\begin{array}{l}17 \\
10\end{array}$ & $\begin{array}{l}35 \\
20\end{array}$ & $\begin{array}{l}\text { Thyroidectomy } \\
\text { After skin incision pt. went into shock. } \\
\text { Bleeding peptic ulcer. Operation } \\
\text { stopped }\end{array}$ \\
\hline $26 b$ & $68 \mathrm{~F}$ & 5 & $\begin{array}{l}\text { Pentothal and } \\
\mathrm{NO}_{2}\end{array}$ & 46 & 55 & 66 & 40 & $\begin{array}{l}\text { Gastric resection. BP low throughout } \\
\text { the procedure }\end{array}$ \\
\hline $\begin{array}{l}27 \\
28 \\
29\end{array}$ & $\begin{array}{l}72 \mathrm{M} \\
56 \mathrm{~F} \\
56 \mathrm{~F}\end{array}$ & $\begin{array}{l}1 \\
3 \\
2 \frac{1}{2}\end{array}$ & $\begin{array}{l}\text { Spinal } \\
\text { General } \\
\text { Spinal and } \\
\text { pentothal }\end{array}$ & $\begin{array}{l}31 \\
41 \\
25\end{array}$ & $\begin{array}{l}26 \\
35 \\
36\end{array}$ & $\begin{array}{l}24 \\
34 \\
40\end{array}$ & $\begin{array}{l}20 \\
18 \\
32\end{array}$ & $\begin{array}{l}\text { Suprapubic prostatectomy } \\
\text { Excision of large abdominal cyst } \\
\text { Smith-Peterson nailing }\end{array}$ \\
\hline $\begin{array}{l}30 \\
31 \\
32 \\
33\end{array}$ & $\begin{array}{l}60 \mathrm{~F} \\
37 \mathrm{~F} \\
57 \mathrm{~F} \\
55 \mathrm{M}\end{array}$ & $\begin{array}{l}4 \\
2 \frac{1}{2} \\
6 \frac{1}{4} \\
4\end{array}$ & $\begin{array}{l}\text { General } \\
\text { General } \\
\text { General } \\
\text { Spinal }\end{array}$ & $\begin{array}{l}19 \\
20 \\
28 \\
12\end{array}$ & $\begin{array}{l}27 \\
30 \\
32 \\
19\end{array}$ & $\begin{array}{l}38 \\
24 \\
34 \\
22\end{array}$ & $\begin{array}{l}40 \\
31 \\
36 \\
23\end{array}$ & $\begin{array}{l}\text { Cholecystectomy } \\
\text { Splenectomy } \\
\text { Cholecystectomy } \\
\text { Open reduction and internal fixation of } \\
\text { hip }\end{array}$ \\
\hline $\begin{array}{l}34 \\
35 \\
36\end{array}$ & $\begin{array}{l}60 \mathrm{~F} \\
38 \mathrm{M} \\
60 \mathrm{M}\end{array}$ & $\begin{array}{l}5 \\
2 \frac{1}{2} \\
5\end{array}$ & $\begin{array}{l}\text { Spinal } \\
\text { Spinal } \\
\text { Cyclo propa. } \\
\text { and } \mathrm{NO}_{2}\end{array}$ & $\begin{array}{r}28 \\
6 \\
13\end{array}$ & $\begin{array}{l}30 \\
16 \\
22\end{array}$ & $\begin{array}{l}26 \\
28 \\
47\end{array}$ & $\begin{array}{l}18 \\
35 \\
33\end{array}$ & $\begin{array}{l}\text { Cholecystectomy. Patient jaundiced } \\
\text { Intramedullary nailing of left femur } \\
\text { Cholecystectomy and duct exploration }\end{array}$ \\
\hline 37 & $62 \mathrm{~F}$ & 7 & $\begin{array}{l}\text { Pentothal and } \\
\text { cyclo }\end{array}$ & 36 & 53 & 60 & 54 & Thyroidectomy \\
\hline 38 & $62 \mathrm{~F}$ & $2 \frac{1}{2}$ & $\begin{array}{l}\text { Spinal and } \\
\text { cyclo }\end{array}$ & 29 & 25 & 29 & 28 & Bilateral sympathectomy \\
\hline $\begin{array}{l}39 \\
40 \\
41 \\
42 \\
43 \\
44\end{array}$ & $\begin{array}{l}60 \mathrm{~F} \\
62 \mathrm{M} \\
25 \mathrm{~F} \\
60 \mathrm{M} \\
42 \mathrm{~F} \\
60 \mathrm{M}\end{array}$ & $\begin{array}{l}3 \\
4 \frac{1}{2} \\
4 \frac{1}{2} \\
5 \frac{1}{2} \\
3 \\
4\end{array}$ & $\begin{array}{l}\text { Spinal } \\
\text { General } \\
\text { General } \\
\text { General } \\
\text { General } \\
\text { General }\end{array}$ & $\begin{array}{l}25 \\
26 \\
42 \\
34 \\
30 \\
30\end{array}$ & $\begin{array}{l}36 \\
33\end{array}$ & $\begin{array}{l}34 \\
40\end{array}$ & $\begin{array}{l}34 \\
20\end{array}$ & $\begin{array}{l}\text { Right colectomy } \\
\text { Gastrectomy } \\
\text { Ligation of patent ductus } \\
\text { Thyroidectomy (substernal) } \\
\text { Removal of cyst of pericardium } \\
\text { Removal of diverticulum of esophagus }\end{array}$ \\
\hline
\end{tabular}

values during the period studied. The rise in 17-hydroxycorticosteroid levels both during and after operations lasting more than two hours was more striking.

The details of the operative procedures in a few of these patients may help to throw light on the significance of the steroid rises. One patient (No. 26) was a 68-year-old white female with auricular fibrillation and severe hemorrhage from a peptic ulcer. The patient had slight persistent bleeding from the ulcer at the time of surgery. On the first occasion, after she had been anesthesized with pentothal and nitrous oxide, her blood pressure fell moderately, immediately following superficial incision. The latter was closed and the patient was returned to the ward where she recovered uneventfully. The 17-hydroxycorticosteroids showed little change following the closure of the incision (lower curve in Figure 3). Without additional blood transfusion or other specific therapy the patient underwent a gastric resection the following day under general anesthesia. In spite of a similar hypotensive reaction an operation lasting five hours was completed successfully. As can be seen in Figure 3 (upper curve) there was a striking rise in 17-hydroxycorticosteroid levels 


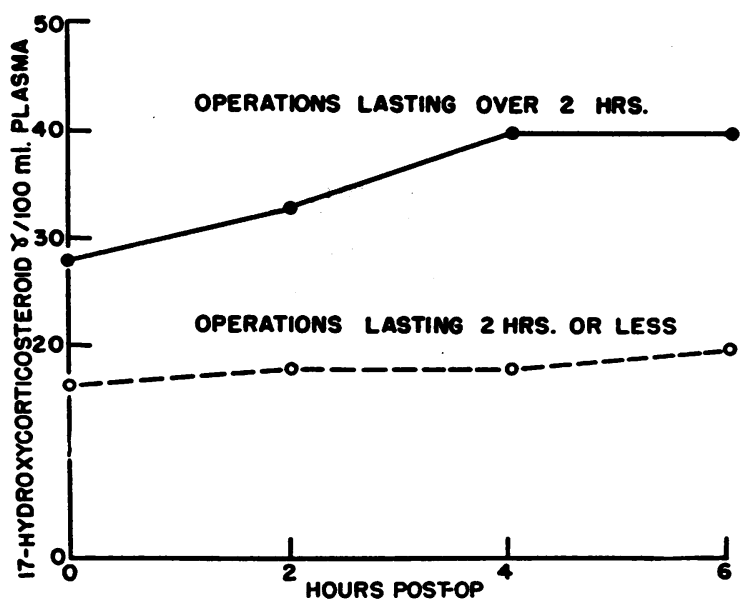

Fig. 2. Average Plasma 17-Hydroxycorticosteroids FOLLOWING SURGERY

after the second operation. This case suggests that the magnitude of the rise in the 17-hydroxycorticosteroid levels in plasma is related to the severity of the surgical procedure and its duration.

In Figure 4 the changes in 17-hydroxycorticosteroids in a 57-year-old female following a cholecystectomy lasting four and one-half hours are shown. After the operation this patient's 17-hy-

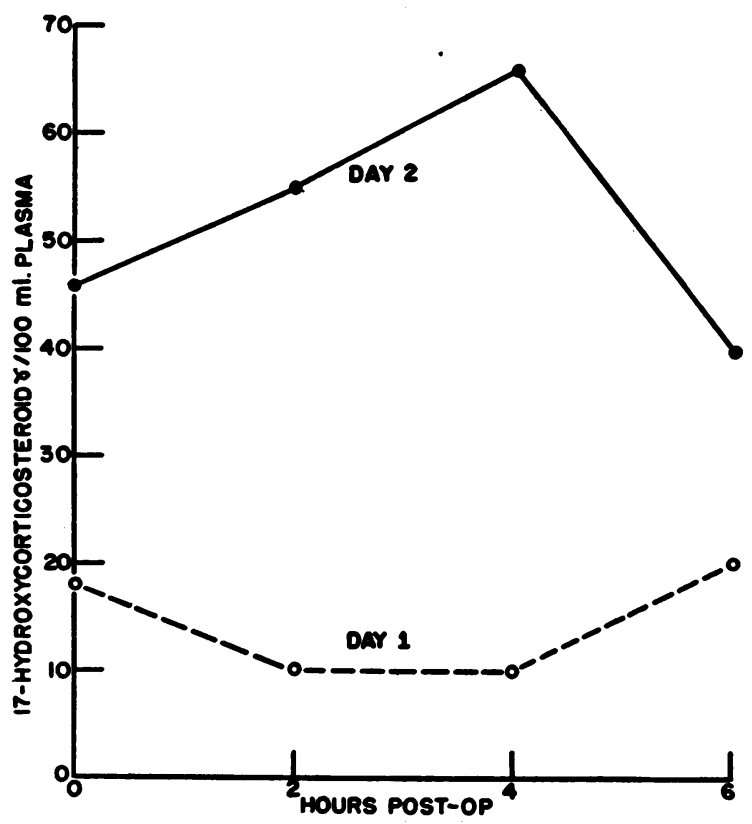

Fig. 3. Plasma 17-Hydroxycorticosteroms in a Patient in Whom Anesthesia Was Given and ONLy a SUperficial Incision was Made on One Day (Lower CURve) and a Subtotal Gastrectomy the following DAy (UPPER CuRve) droxycorticosteroid level reached $148 \mu \mathrm{g}$ per 100 $\mathrm{ml}$. of plasma. Such levels have not been observed in other subjects not undergoing surgery who were not moribund, even following the continuous intravenous administration of maximally stimulating doses of ACTH over a period of 48 hours. This patient died 36 hours following the operation.

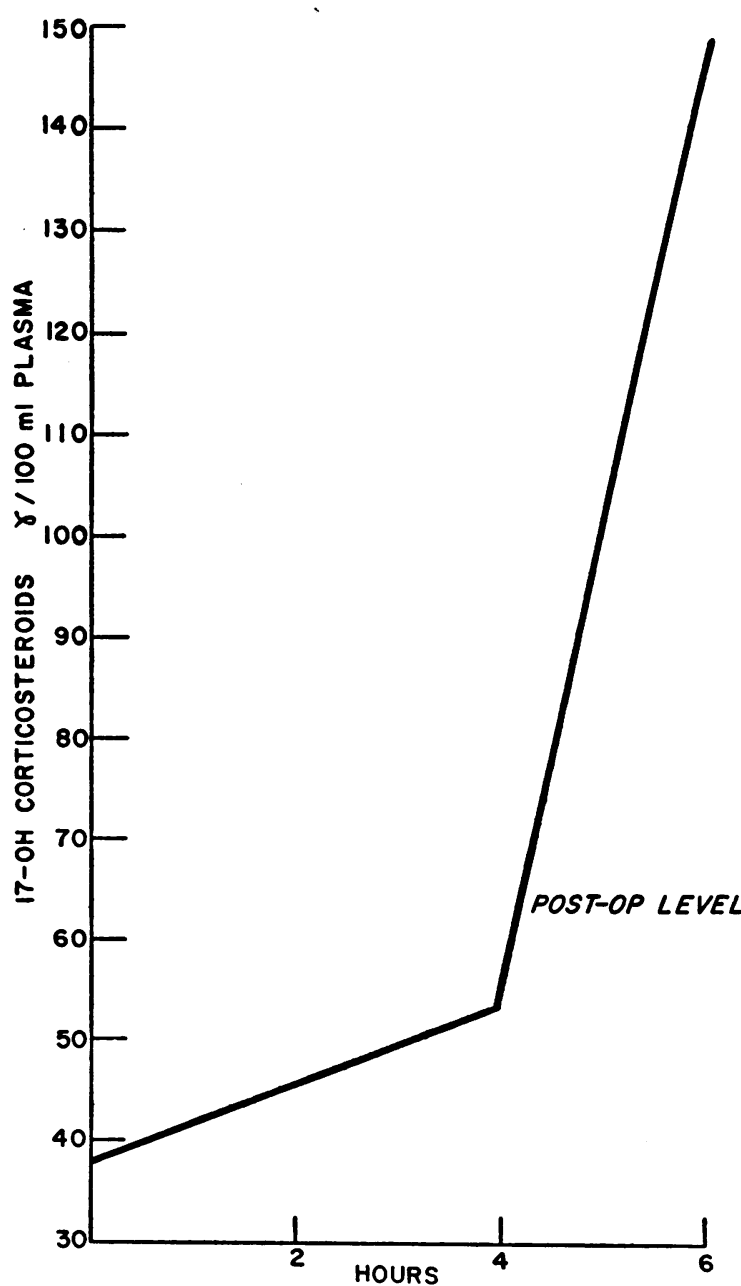

Fig. 4. Plasma 17-Hydroxycorticosteroids in a Patient Following Cholecystectomy Lasting Four and ONe-Half Hours

\section{$A C T H$ response pre- and post-operatively}

Standard ACTH response tests were performed on six surgical patients at least one week before the operation. In each case a normal rise in 17hydroxycorticosteroid levels occurred (Figure 5). After operation a similar rise was observed when 

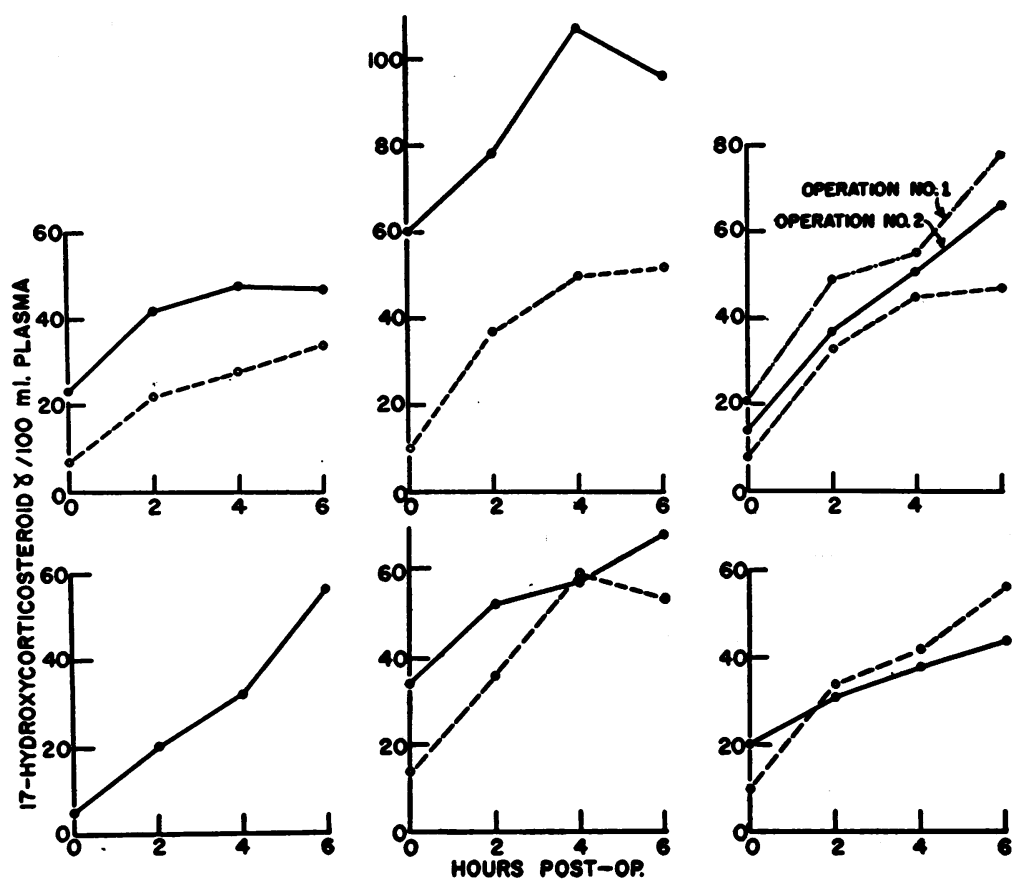

Fig. 5. Response of Plasma 17-Hydroxycorticosteroms to 25 I.U. ACTH Intravenously on a Control Day (Broken Lines) and following Major Surgery (Solid Lines)

ACTH was given intravenously regardless of the levels of the steroids at the end of the procedure. In one of these cases the postoperative 17-hydroxycorticosteroid level was $60 \mu \mathrm{g}$ per $100 \mathrm{ml}$. of plasma, a level compatible with maximal adrenal cortical stimulation. Interestingly enough, the administration of ACTH was associated with a further rise (up to $107 \mu \mathrm{g}$ per $100 \mathrm{ml}$. of plasma) in the level of plasma 17-hydroxycorticosteroids; the magnitude of the rise was as great as that seen in the control curve in this patient or in normal unstressed individuals.

\section{The effects of surgery on the blood levels produced by intravenously administered steroids}

Each of five surgical patients was given hydrocortisone intravenously on two occasions. A control injection was given at least one week before or four weeks after the operation. The same patients received hydrocortisone during or following their operation. On each occasion the plasma 17hydroxycorticosteroid levels were measured for a period of 8 hours (Figure 6 ). In three patients (G, $\mathrm{H}$ and $\mathrm{I}$ ) the levels of 17-hydroxycorticosteroids reached higher values and were maintained at higher levels after surgery than during the control periods. In two cases ( $\mathrm{J}$ and $\mathrm{K}$ ), the disappearance curves were not significantly different on the operative day than on the control day.

\section{DISCUSSION}

From the data presented here it appears that there are at least two factors associated with surgical procedures which affect the levels of adrenal steroids in the general circulation; induction of anesthesia and the actual handling of tissues. Spinal anesthesia had little effect on the plasma 17-hydroxycorticosteroid levels preoperatively, while general anesthesia produced a definite increase in most cases, even though the subsequent operation may have had little effect. The independence of these two effects is shown by the fact that the post-surgical rises were similar regardless of the type of anesthesia used.

The post-surgical rise would appear to be a continuation of the rise during surgery rather than a separate phenomenon. Both were correlated with the length of operation and the extent of tissue trauma. The post-operative rise probably is the result of the continued presence of damaged tis- 
sues. Epinephrine apparently is not involved since the plasma 17-hydroxycorticosteroids fail to rise following its administration (9).

The adrenals of these patients were certainly not maximally stimulated, since the administration of ACTH was associated with an additional rise above the high levels of 17-hydroxycorticosteroids induced by the surgical procedures. It is of interest that in a few patients the rate of rise of the steroid level, either when ACTH was given or in its absence, exceeded that which we have observed in surgical patients or in normal individuals receiving amounts of $\mathrm{ACTH}$ which produce maximal rises in plasma 17 -hydroxycorticosteroid levels under basal conditions. Thus, the data cannot be explained entirely by endogenous ACTH secretion. It must, therefore, be concluded that factors other than adrenal cortical stimulation play a part in raising the steroid concentrations during and subsequent to surgery. It follows that the removal of adrenal steroids from the circulation may be impaired. That this is a significant factor is suggested by the decreased rate of disappearance of injected hydrocortisone in three of the five patients in whom this type of study was performed during or immediately after surgery. There is evidence to suggest that the liver has an important role in these processes. Data concerning the importance of the liver in the metabolism of adrenal steroids is being presented in other papers of this series $(18,19)$.

It should be emphasized, however, that these data do not exclude the possibility that the adrenal cortex is stimulated submaximally by the surgical trauma. Indeed, if the spontaneous post-surgical rises in plasma 17-hydroxycorticosteroid level were entirely due to impaired extra-adrenal metabolism and excretion of these compounds, we should have observed supramaximal rises regularly when ACTH was administered in the presence of an already elevated level. The rate of disappearance of the additional steroid secreted by the stimulated adrenal would also presumably have been impaired, resulting in increments of considerably greater magnitude than those observed under basal circumstances. This was clearly not the case. Similarly each patient receiving exogenous steroid at a time when his level was elevated should have shown markedly impaired removal of the steroid if the elevation

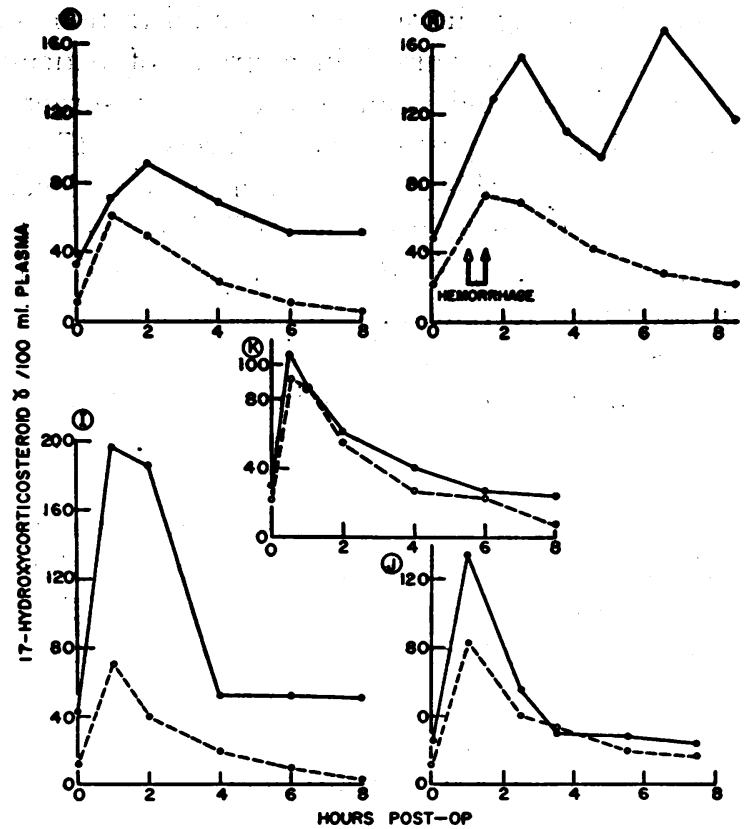

Fig. 6. Plasma 17-Hydroxycorticosteroids following Intravenous Administration of 50 mg. of HydroCortisone on a Control Day (Broken Line) aNd folLOWING SURGịry (SOLId Lines)

resulted only from a decreased rate of removal. Thus these data suggest a combined effect of increased production and decreased removal.

Although the increased plasma 17-hydroxycorticosteroids in the post-surgical period probably are metabolically active, whether the higher levels are due to increased adrenal secretion or impaired disposition, for the reasons considered in the introduction, our finding that surgical trauma is associated with an increase in the levels of circulating adrenal steroids does not necessarily indicate that the entire adrenal-like metabolic response to surgery is mediated by these rises.

\section{SUMMARY}

1. The plasma levels of 17-hydroxycorticosteroids were determined in a group of surgical patients. They were found to be elevated following the induction of anesthesia and during and after surgery. Following surgery the increases were roughly proportional to the duration and severity of the operative procedure. This elevation usually persisted at least 6 hours following surgery.

2. In an attempt to measure adrenal cortical capacity, the changes in 17-hydroxycorticosteroid 
levels following intravenous administration of $\mathrm{ACTH}$ were determined in a group of patients preoperatively, and again shortly after surgery. Even when the post-operative levels of 17-hydroxycorticosteroids rose spontaneously to levels as high as those induced by ACTH in normals, the administration of ACTH was associated with an additional increment.

3. Some patients undergoing surgery did not metabolize intravenously administered hydrocortisone as rapidly after surgery as they did on control days.

4. The data seem most consistent with the hypothesis that the adrenal is submaximally stimulated by surgical trauma but that impaired disappearance of circulating steroid also contributes to the rises observed.

\section{ACKNOWLEDGMENTS}

We are grateful to Dr. E. M. Alpert of Merck and Company for generous supplies of steroids and to Dr. E. E. Hays of Armour and Company for generous supplies of ACTH. We wish to extend special thanks to the members of the Department of Surgery and Anesthesia for their whole hearted cooperation in making this study possible.

\section{REFERENCES}

1. Sayers, G., The adrenal cortex and homeostasis. Physiol. Rev., 1950, 30, 241.

2. Selye, $H$., The general adaptation syndrome and the diseases of adaptation. J. Clin. Endocrinol., 1946, 6, 117.

3. Sayers, G., and Sayers, M. A., Regulation of pituitary adrenocorticotrophic activity during the response of the rat to acute stress. Endocrinology, 1947, 40, 265.

4. Ingle, D. J., Ward, E. O., and Kuizenga, M. H., The relationship of the adrenal glands to changes in urinary non-protein nitrogen following multiple fractures in the force-fed rat. Am. J. Physiol., 1947, 149, 510.

5. Ingle, D. J., Meeks, R. C., and Thomas, K. E., The effect of fractures upon urinary electrolytes in non-adrenalectomized rats and in adrenalectomized rats treated with adrenal cortex extract. Endorinology, 1951, 49, 703.

6. Engel, F. L., A consideration of the roles of the adrenal cortex and stress in the regulation of protein metabolism. Recent Progress in Hormone Research, 1951, 6, 277.

7. Cannon, W. B., The Wisdom of the Body. New York, W. W. Norton \& Co., 1939, 333 p.

8. Best, W. R., Muehrcke, R. C., and Kark, R. M., Studies on adrenocortical eosinopenia: A clinical and statistical evaluation of four-hour eosinophil response tests. J. Clin. Invest., 1952, 31, 733.

9. Sandberg, A. A., Nelson, D. H., Palmer, J. G., Samuels, L. T., and Tyler, F. H., The effects of epinephrine on the metabolism of 17-hydroxycorticosteroids in the human. J. Clin. Endocrinol. \& Metab., 1953, 13, 629.

10. Moore, F. D., and Ball, M. R., The Metabolic Response to Surgery. Springfield, Ill., Charles C Thomas, 1952.

11. Roche, M., Thorn, G. W., and Hills, A. G., The levels of circulating eosinophils and their response to ACTH in surgery. New England J. Med., 1950, 242, 307.

12. Sayers, G., and Sayers, M. A., The pituitary-adrenal system. Recent Progress in Hormone Research, 1948, $2,81$.

13. Eik-Nes, K., Sandberg, A. A., Nelson, D. H., Tyler, F. H., and Samuels, L. T., Changes in plasma levels of 17-hydroxycorticosteroids during the intravenous administration of ACTH. I. A test of adrenocortical capacity in the human. J. Clin. Invest., 1954, 33, 1502.

14. Eik-Nes, K., Nelson, D. H., and Samuels, L. T., Letter to the editor. J. Clin. Endocrinol. \& Metab., 1953, 13, 1280.

15. Randolph, T. G., Blood studies in allergy. I. The direct counting chamber determination of eosinophils by propylene glycol aqueous stains. J. A1lergy, 1944, 15, 89.

16. Sandberg, A. A., Nelson, D. H., Glenn, E. M., Tyler, F. H., and Samuels, L. T., 17-Hydroxycorticosteroids and 17-ketosteroids in urine of human subjects; Clinical application of a method employing $\beta$-glucuronidase hydrolysis. J. Clin. Endocrinol. \& Metab., 1953, 13, 1445.

17. Bliss, E. L., Sandberg, A. A., Nelson, D. H., and Eik-Nes, K., The normal levels of 17-hydroxycorticosteroids in the peripheral blood of man. J. Clin. Invest., 1953, 32, 818.

18. Brown, H., Willardson, D. G., Samuels, L. T., and Tyler, F. H., 17-Hydroxycorticosteroid metabolism in liver disease. J. Clin. Invest., 1954, 33, 1524.

19. Tyler, F. H., Schmidt, C. D., Eik-Nes, K., Brown, H., and Samuels, L. T., The role of the liver and the adrenal in producing elevated plasma 17-hydroxycorticosteroid levels in Surgery. J. Clin. Invest., 1954, 33, 1517. 